\title{
Preliminary impact assessment of the new transport infrastructure project on Trans-Baikal Territory geosystems, Russia
}

\author{
N. Pomazkova ${ }^{\mathbf{1}^{*}}$, L. Faleychik ${ }^{\mathbf{1}}$, A. Faleychik ${ }^{2}$ \\ ${ }^{I}$ Institute of Natural Resources, Ecology and Cryology, Russian Academy of Sciences, Siberian Branch, Nedorezov street \\ Chita, Russia. \\ ${ }^{2}$ Transbaikal State University, Alexandro-Zavodskaya street, Chita, Russia.
}

\begin{abstract}
Received 04 Dec 2017,
Revised 05 Feb 2018 ,

Accepted 10 Feb 2018

\section{Abstract}

Transbaikalia is in the interest area of the largest foreign policy initiative of China - the project "Silk Road Economic Belt". The creation of the infrastructure linking member states (China, Russia, Mongolia) is one of the priority directions of this cooperation.

Keywords First of all, the possibility of constructing a high-speed railway (HSR) is discussed. It is known that HSRs exert an overall positive effect on the development of regional economies, especially on such brunches as tourism and regional cooperation. However this initiative carries risks for the natural ecosystems of the region such as: land take, biodiversity loss, degradation and fragmentation of habitats, increasing pollution, barrier effects, noise, land use impacts. This paper is focusing on the potential impacts of under project on the geosystems. The spatial analysis results show that the project is likely to endanger 43 out of 122 natural geosystems located on the Trans-Baikal Territory. Along them there are 5 types of rare landscapes and 6 landscape types which are not presented in region NPAs network. According to the proposed route version, it won't cross any border of any nature reserve. To mitigate and compensate the negative impact of the new transport facility on the region geosystems the measures are suggested.

naste2@yandex.ru

Phone: +79144839713
\end{abstract}

\section{Introduction}

The comparison of the density of railways in the Trans-Baikal Territory (TBT)reveals that the territory is poorly developed in contrast to the Asia-Pacific countries, European part of Russia and Europe. The boundary between the zones of transport and economic impact of the European and Asian centers crosses the west of the Irkutsk region [1].

The geographical proximity of a large, rapidly growing state cannot but lead to the involvement of neighboring regions territories in strategic world projects. By 2020 China's whole rail network is planned to be $120,000 \mathrm{~km}$ long, including 16,000 km of new high-speed railroads. As a result China's high-speed rail network will connect the centers of all provinces and cities with a population of more than 500000 , covering thus more than $90 \%$ of the population of the country, its length will exceed $50000 \mathrm{~km}[2]$.

At present, TBT is territorially located in the zone of interests of the largest foreign policy initiative of China - Silk Road Economic Belt (SREB), a part of the system project One Belt, One Road (OBOR). SREB concept provides a comprehensive deepening of trade-economic, transport and logistics links between the countries of Asia-Pacific region, a priority avenue of cooperation is the creation of the infrastructure that will link member states (China, Russia and Mongolia). In the first place the possibility of building a high-speed traffic artery is considered.

The initial scheme of Silk Road Economic Belt project transport infrastructure in addition to the traditional three routes through the European part of Russia, Kazakhstan, Turkey, Iran, Georgia and Azerbaijan also includes a route through the Western and Eastern Siberia and the Far East (Figure 1). It should facilitate the development of the north-eastern regions of China in accordance with the prospects "Northeast Revitalization Plan" and "The Development of Western China". "For example, Li Xin, a researcher at the Shanghai Institutes 
for International Studies, suggests that among the Chinese, Mongolian, Russian economic corridors, the most important route is Chita - Manzhouli - Harbin - Suifenhe - Vladivostok, and this route will link to the TransSiberian Railway. This is the main route which will connect Heilongjiang Province to Europe" [3, p. 5].

The Belt and Road Initiative: Six Economic Corridors Spanning Asia, Europe and Africa

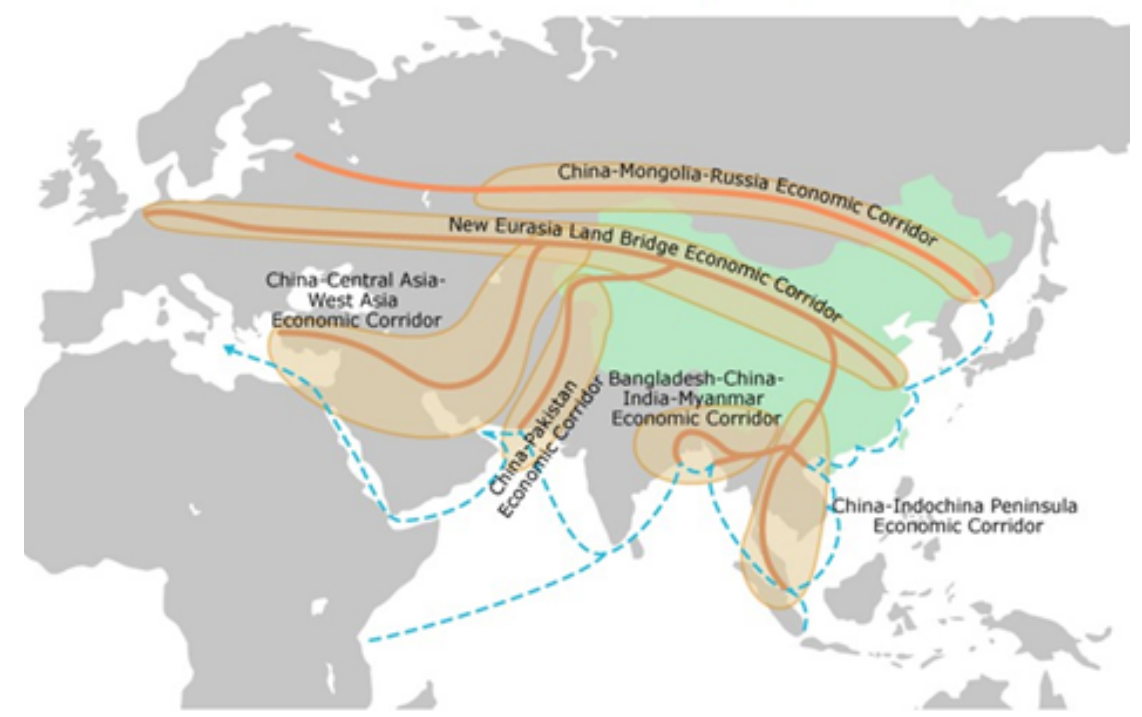

Figure 1:SREB transport corridors scheme(http://china-trade-research.hktdc.com/business-news/article/The-Belt-andRoad-Initiative/The-Belt-andRoad-Initiative/obor/en/1/1X000000/1X0A36B7.htm).

In accordance with this scheme the Trans-Siberian Transport Corridor of high-speed railway (HSR) will link Russia and Asia-Pacific countries. The project will involve public-private partnerships analogous to those existing in the sphere of mineral resources development [4]. Thus, the project will serve not only the purposes of transit transport, but its implementation should contribute to closer economic consolidation and economic development of the eastern regions of Russia adjacent to the corridor [5, 6].

The study of high-speed networks impact on the economies of adjacent territories shows the total positive effect for regional development [7, 8], especially in such areas as tourism [9] and regional cooperation [10]. At the same time, like any other economic entity, the initiative carries risks for the natural ecosystems of the region. Not only during the construction period, but also as a new member of regional economy, the road will propel the region development being the onset of the possible consequences in the future since it will cause changes in land use and settlement and will stimulate the further development of the road network itself, and so on.

However, the population of the eastern regions of Russia bordering China worries about Russian-Chinese cooperation projects. Long-term experience of cross-border cooperation shows that the socio-economic prospects often entail challenges, including environmental ones [11-13]. The situations of ecologically unequal exchange when short-term benefits go to investors whereas the public faces irreversible changes in ecosystems up to environmental disasters occur rather often [13].

Environmental aspect of this initiative study is very important: environmental safety is a part of SREB strategy. The documents on SREB also clearly formulate environmental goals, "the core ideology is to respect nature, to follow nature, and to protect nature, and to drive human sustainable development" [6, p. 69].

It is important to carry out this study at the pre-stage in order to manage to schedule compensatory measures and maximally envisage the consequences which may then be difficult to remedy. The formation of projects and programs of Silk Road Economic Belt should be based on the principles of "green" economy and not allow for changes in the existing environmental and economic situation for the worse. A New Silk Road should become a road to "green" economy for TBT [14-15], and be an example of "green transportation infrastructure" [16].

The Trans-Baikal Territory is located in the south of Eastern Siberia, far away from sea transport routes and borders with China and Mongolia. The transport network in Zabaykalsky Krai contains more than $21000 \mathrm{~km}$ of roads, and $3400 \mathrm{~km}$ of railways. In terms of nature it is a mountainous land [17-18], which is located in a region of intense response to climatic changes[19], of high landscape and biological diversity [20-22]. At the same time, the area has a special biosphere value: most of it is located within three globally significant ecoregions identified according to Global 200 initiative of the World Wildlife Fund [23]. Therefore, the risk assessment for natural complexes during high-speed railway construction is an urgent task. 
The interest to the issues of roads impact on the surrounding area and landscapes becomes weaker, as can be seen from regular publications on this subject [24-26] and international conferences discussions. However, most publications are focused on the issues of sustainable transport development, life quality improvement, land use patterns changes and so forth [27-29]. Often discuss "environmental" benefits of HSRs only compared to conventional railways, road and air transport because they are more energy efficient, produce less GHG (greenhouse gases) and dust, have a lower level of noise impact or the infrastructure protecting against it, occupy a smaller land in comparison with a highway and so on [30-31].

However HSRs are roads, like all other engineering structures of this type, impact on landscapes abiotic components - surface and underground waters, soils, microclimate, flora and fauna [32]. The degree and intensity of the influence on the natural complexes depend on the position of a road relative to slopes, prevailing winds and surrounding landscape [25]. Besides, road construction and its operation are accompanied by an increase of chemical compounds and dust in the surrounding territories. The impact of roads as barriers to animals is most often noted in environmental studies. At the same time, the extent of the adverse effect of a road depends on the nature of the road, its spatial configuration with respect to neighboring landscapes and specific species behavior. There is ample evidence for the negative effects of transportation infrastructure on nature. Such an effect is noted for small [33] and large mammals [34],birds [35] and even insects [36]. The works of many authors are devoted to the assessment of the effect of roads on the landscape, their fragmentation consequences [36-43]. Habitat fragmentation, on many researchers' opinion, is the greatest and most serious threat to nature. Fragmentation of habitats has implications for biological diversity loss at species, population and genetic levels.

Direct and indirect impact, the cumulative effect of all the factors on the landscape as a system are less studied, however it is noted that roads and road networks have a synergistic effect on ecosystems [30]. Since most of the roads cross a few types of landscapes and ecosystems, the numerous attempts of comprehensive ecological and economic risk and vulnerability assessment of ecosystems using different indices were made [4446].

Despite the fact that the road is quite narrow linear structure which doesn't occupy large areas, the zone of its impact on surrounding landscape is much broader. The intensity and area of road impact on the surrounding area change and may have different coverage, depending on the sensitivity and vulnerability of species and ecosystems. Currently, the tools to assess all the roads impact complex are not sufficiently developed [47]. Widespread impacts can occur many kilometers from the project. These impacts are often linked to indirect effects that arise over the medium or long-term existence of the project and include the influx of settlers, deforestation, and the development of new industries. It was found that road impact goes far beyond just the railroad bed or a land plot designated for its allocation. Major habitat conversion can take place into a $10 \mathrm{~km}$ zone along the road [48]. This zone can be asymmetrical, with intricate borders reflecting the geomorphological and other features of the area.

The objectives of this study do not include the assessment of the impact made by the entire range of factors and comprehensive coverage of the problems that arise when implementing this initiative. The purpose is to identify and evaluate the territory natural areas loss risks when implementing of this project.

In this study authors attempt to follow the ideas of the Strategic Environmental Assessment (SEA), the practice of which serves as a basis for avoiding negative impacts.

\section{Material and Methods}

The task to identify risks for natural geosystems from HSR project implementation in the region was divided into 2 parts:

1) identify which natural systems of the region are most likely to be affected or changed, to analyze whether these areas are included in the existing network of NPAs;

2) determine whether the existing and planned protected natural areas of TBT will be significantly affected.

It is assumed that the Russian part of HSR route passing through TBT will start from Zabaykalsk station (border transition between Russia and China), pass through the regional center (the city of Chita) further bypassing the city of Petrovsk-Zabaykalsky, reach the capital of the Republic of Buryatia (Ulan-Ude), with the subsequent crossing of the recreational areas of the lake Baikal (Irkutsk), with the prospect of continuing in the direction of the economic centers of Siberia and further to Central Russia.

Currently, high-speed trunk-railway is not yet designed. However, according to one of the three options for moving cargoes and passengers in the territory of the region it will pass along the already functioning trunkrailway. That is why a zone along the existing Zabaykalsk - station Chita - Petrovsky Zavod station parcel is selected as the area for its construction (the study area) (Figure 2). 


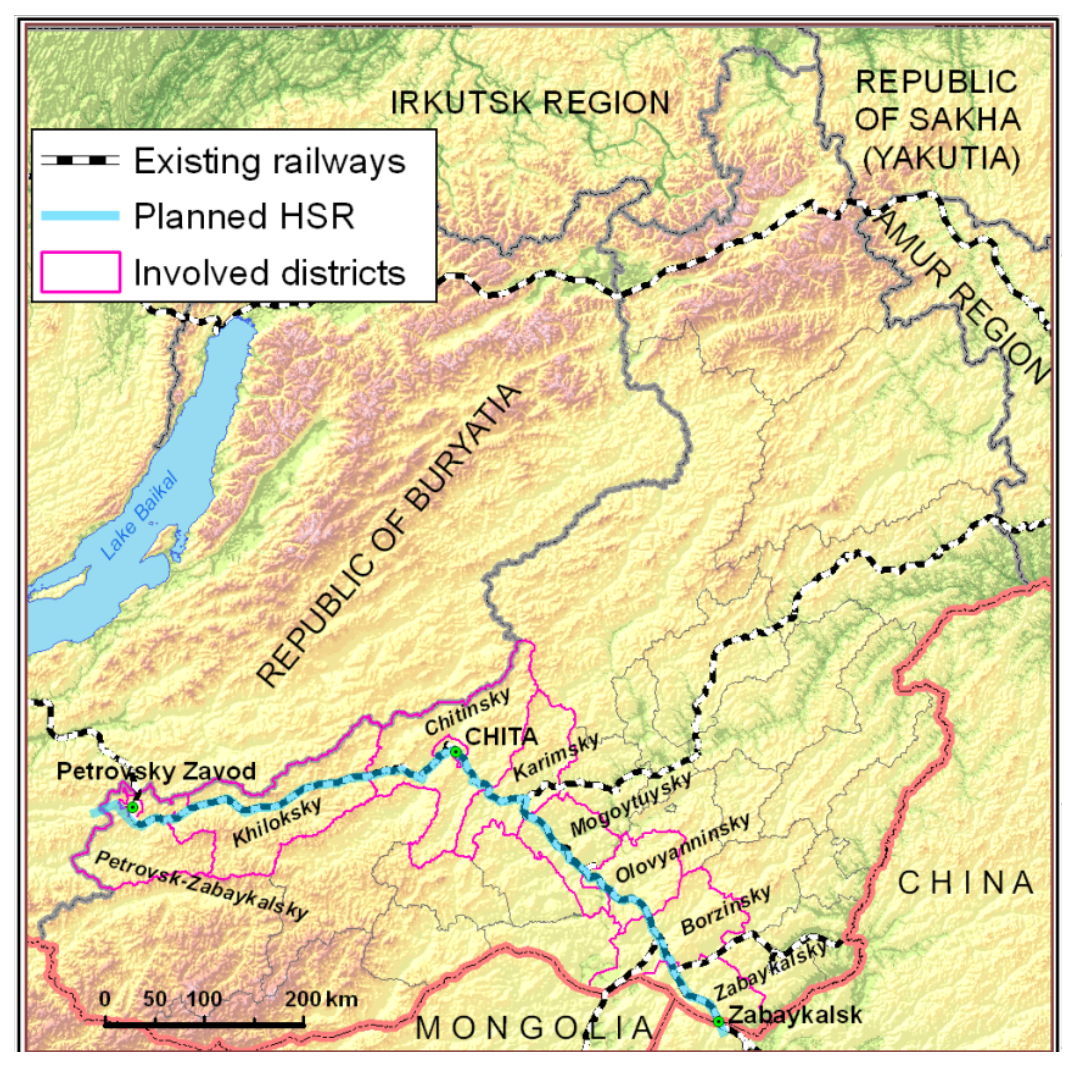

Figure 2 :HSR option for the Trans-Baikal Territory.

Technologies of geographic information systems (GIS) are widely used in the environmental impact assessment process. However, initially the GIS use within the ecological assessment was usually limited to its visualization functions, and its analytical capacities were seldom used [49]. At present, many researchers commonly include the analytical GIS tools, the spatial analysis and modelling methods in their studies. It is believed that the GIS technologies use provide an easily interpretable and unbiased environmental impact assessment [50]. The authors have used GIS analysis early in the environmental impact access for several Russian projects [51-61].

The task of the identification of the natural complexes, which may be affected by exposure to various aspects of the construction and operation of HSR, was solved in the GIS application - ArcGIS for Desktop.

The data of the interferometric recording of the globe, Shuttle Radar Topography Mission (SRTM), were used as a general geographic base [62]. The vector thematic layers, representing the topographic base of the territory, infrastructure objects and thematic layers of the map "The landscapes of the south of the Eastern Siberia" of 1: 1500000 scale [63], existing NPA network circuits and designed protected areas according to Integrated NPA Development Program in Zabaykalskiy region were used in spatial analysis.

In addition, the results of the authors' earlier studies were used for the landscapes evaluation and classification $[22,61]$.

A $10 \mathrm{~km}$ wide buffer zone centered at the selected line was constructed in ArcGIS. The size of the zone was determined by the task of the more complete assessment of the potential risks associated with the different possible options for the line construction, taking into account the existing roads impact areas assessments [26, 48]. The landscape areas that fall into this zone, as well as their spatial location analysis relative to the nature protected areas network are identified and evaluated using overlay procedures.

\section{Results and discussion}

Trans-Baikal section of high-speed trunk-railway (according to one of the most promising options) will pass along the existing railway line through the territory of 8 districts of the region. Conditional HSR scheme is shown in Figure 2. The total area of the districts involved in the project is 75 thousand $\mathrm{km}^{2}$. The high-speed line construction requires the allotment of lands for temporary and permanent use. The width of the permanent land allotment - about 60 meters - is required for placement of the linear part of HSR, station sites and facilities. 
Temporary land occupation is required for the construction process organization: tracks for construction equipment, construction sites and shift camps organization and building materials storage.

Landscape and vegetation will be affected at all stages of the project: 1) design, 2) construction and 3) functioning of HSR. However, the greatest impact accounts for the construction period. These changes will be both quantitative - the reduction of vegetation and loss of the natural landscape in an easement for constructionand qualitative. The qualitative changes of vegetation will relate to changes in floral composition and structure (pauperization and extinction of natural flora and wider spread of synanthropic and weed plants) and so forth.

In accordance with physiographic zoning scheme HSR line crosses the following physiographic regions and provinces: Central Asian desert-steppe region and two provinces of South Siberian mountainous area Ingodino-Onon basin midmountain area and Khilok-Udinsk steppized midmountain area [18]. Mountainous basin relief determines the location of the planned object along the bottom of the slopes and in river valleys. Thus, steep and meadow coenoses along rivers will be increasingly affected, as well as treeless or steep areas at the foot of slopes.Taiga landscapes of the middle and upper parts of the ridges in the places of their intersection with transport corridor will be affected to a lesser extent.

Spatial analysis performed in ArcGIS allowed revealing landscapes and protected areas falling in the transport corridor - a buffer zone, constructed along the planned HSR ( $5 \mathrm{~km}$ from the both sides of the road). In accordance with the landscape map [63] 43 of 122 geosystems forming the landscape structure of TBT fall in this corridor (Figure 3, Table 1). The abundance of each geosystems identified in the territory of the region as well as its representation in the existing network of NPAs was assessed. In Figure 3 and Table 1 the landscapes facies class numbers and names are given in accordance with the map "Landscapes of the south of Eastern Siberia" [63], and below in the text class numbers are indicated in brackets.

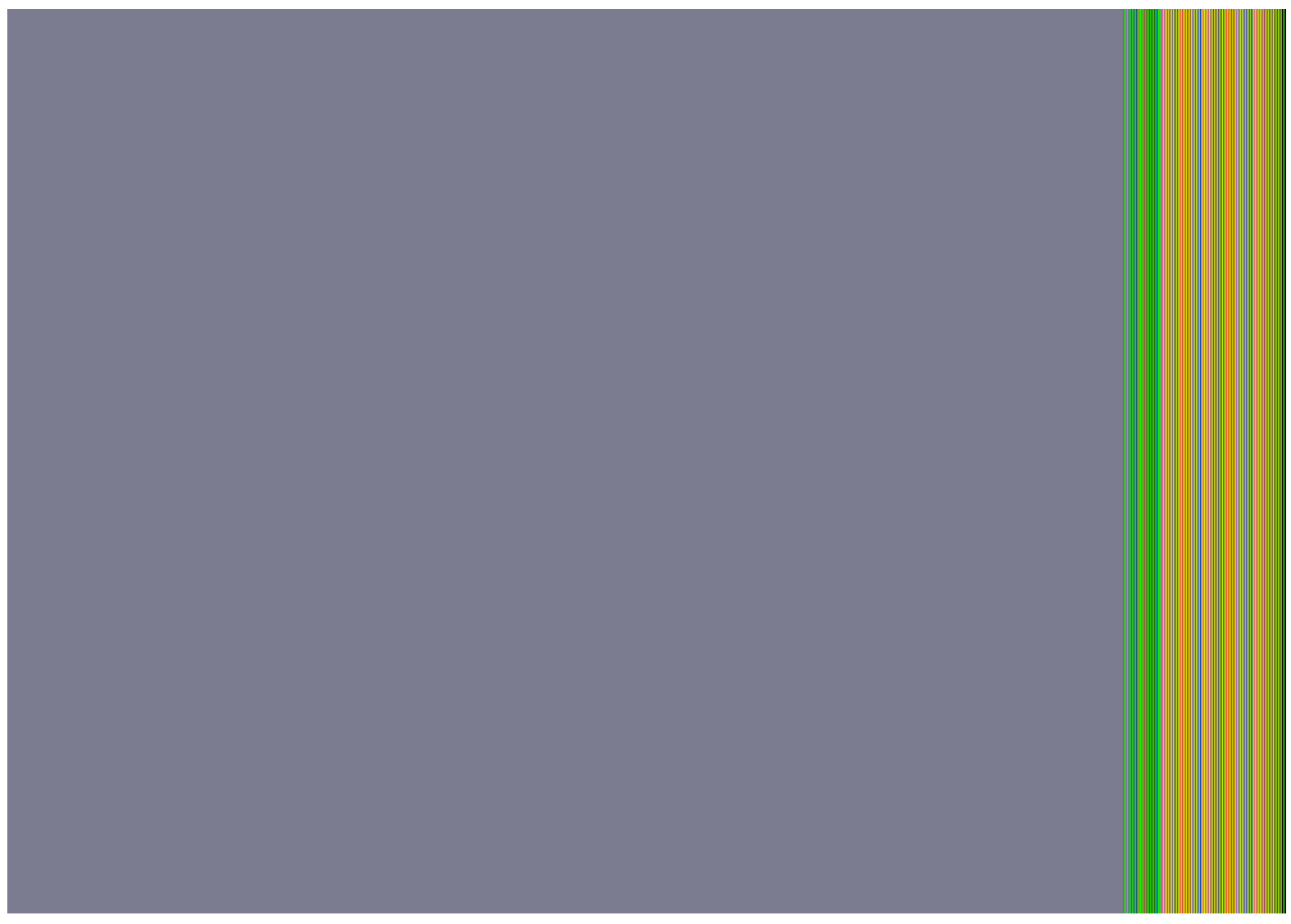

Figure 3: Natural complexes of TBT in the corridor of the planned HSR.

In the south-eastern part of the planned corridor landscape structure is basically created by Central Asian steep landscapes of two formations: mountainous Trans-Baikal of Dahurian type and high plains, Onon-Argunsk gemicyrophile. Here dominate different combinations of low shallowsoddy and mixed herbs steppes, occupying valleys, plains and lowlands. In the depressions they turn into meadow-bogs, meadow-swamps or brackish communities. Here peculiar type of vegetation - Daurian prairie (combination of steppes with trees and shrubs, formed by xerophyte (xerophilous) arborial and dumetosous plant species with an admixture of steppe herbs) is allocated [64]. Steppe and forest-steppe territories of TBT have very large biospheric value: they are home to 
about 60 species of mammals, 330 species of birds, 40 species of fish, 9 species of amphibians and reptiles, more than 2000 species of insects and 800 species of vascular plants [21].

Table1:Geosystems of the Trans-Baikal Territory along the planned HSR line

\begin{tabular}{|c|c|c|c|c|c|}
\hline \multirow{2}{*}{$\begin{array}{l}\text { Landscapes } \\
\text { facies class } \\
\text { number }\end{array}$} & \multirow[b]{2}{*}{ Landscapes facies class } & \multirow{2}{*}{$\begin{array}{l}\text { The total } \\
\text { area } \\
\text { within } \\
\text { HSR } \\
\text { corridor } \\
\text { (sq. } \mathrm{km} \text { ) }\end{array}$} & \multicolumn{3}{|c|}{$\begin{array}{c}\text { Share of the total area of } \\
\text { the corresponding } \\
\text { landscape in }\end{array}$} \\
\hline & & & $\begin{array}{l}\text { TBT } \\
(\%)\end{array}$ & $\begin{array}{c}\text { actual } \\
\text { NPAs } \\
\text { in TBT } \\
(\%)\end{array}$ & $\begin{array}{l}\text { projected } \\
\text { NPAs in } \\
\text { TBT }(\%)\end{array}$ \\
\hline & \multicolumn{5}{|c|}{ A NORTH ASIAN BALD AND TAIGA GEOSYSTEMS } \\
\hline & \multicolumn{5}{|c|}{ A-2 Mountain taiga Baikal Dzhugdzhur } \\
\hline & \multicolumn{5}{|c|}{ IX Mountain taiga larch of limited development } \\
\hline 47 & $\begin{array}{l}\text { Planed surfaces with mixed undergrowth, with a } \\
\text { predominance of bushy birches }\end{array}$ & 32.41 & 0.13 & 5.56 & 3.25 \\
\hline 48 & Slope drift deluvium with mixed undergrowth & 6.35 & 0.03 & 2.84 & 3.91 \\
\hline \multirow[t]{2}{*}{58} & Slope with cedar and mixed undergrowth & 4.98 & 0.04 & 25.71 & 2.51 \\
\hline & \multicolumn{5}{|c|}{$\mathrm{X}$ Intermountain depressions and valleys, larch taiga, of limited development } \\
\hline \multirow[t]{2}{*}{71} & $\begin{array}{l}\text { Valley, of wetland meadows combined with } \\
\text { swamps and bushy birches }\end{array}$ & 119.86 & 4.15 & 1.41 & 1.72 \\
\hline & \multicolumn{5}{|c|}{ XI Mountain taiga, larch, of optimal development } \\
\hline 73 & Flat surfaces with dumetosous undergrowth & 92.91 & 0.68 & 10.05 & 5.11 \\
\hline 74 & $\begin{array}{l}\text { Slope, with dumetosous undergrowth, with a } \\
\text { predominance of Dahurian rhododendron }\end{array}$ & 577.68 & 1.64 & 14.13 & 3.09 \\
\hline 76 & Slope grassy steppe & 229.95 & 1.41 & 2.61 & 6.85 \\
\hline 77 & $\begin{array}{l}\text { Slope birch, larch and herbal combined with } \\
\text { forest skirt meadows and forb steppes }\end{array}$ & 264.35 & 2.74 & 2.64 & 3.04 \\
\hline 78 & Slope with pine and mixed undergrowth & 13.71 & 0.78 & 4.01 & 1.94 \\
\hline 79 & $\begin{array}{l}\text { Slope with an admixture of pine and an } \\
\text { undergrowth of Dahurian rhododendron }\end{array}$ & 93.19 & 0.45 & 8.58 & 3.41 \\
\hline \multirow[t]{2}{*}{81} & Slope pine-larch cowberry forb & 46.88 & 99.64 & 0.00 & 0.00 \\
\hline & \multicolumn{5}{|c|}{ XII Piedmont and intermountain depressions of larch taiga, of optimal development } \\
\hline 85 & Valley dumentosousmeadows & 164.11 & 13.01 & 0.00 & 0.00 \\
\hline 86 & $\begin{array}{l}\text { Valley meadows with gramineous, sometimes } \\
\text { steppizated covering }\end{array}$ & 171.36 & 3.61 & 12.72 & 2.40 \\
\hline \multirow[t]{2}{*}{88} & $\begin{array}{l}\text { Larch piedmont elevations with birches and } \\
\text { herbal dumetosous undergrowth }\end{array}$ & 124.69 & 23.91 & 52.65 & 0.00 \\
\hline & \multicolumn{5}{|c|}{ XIII Piedmont subtaiga larch } \\
\hline \multirow[t]{3}{*}{92} & $\begin{array}{l}\text { Terraces and trails with rare herbal undergrowth, } \\
\text { sometimes steppizated }\end{array}$ & 160.41 & 36.38 & 26.17 & 0.00 \\
\hline & \multicolumn{5}{|c|}{ A-3 Mountain taiga South Siberian } \\
\hline & \multicolumn{5}{|c|}{ XX Mountain taiga pine } \\
\hline 125 & $\begin{array}{l}\text { Flat surfaces with an undergrowth of Dahurian } \\
\text { rhododendron }\end{array}$ & 77.41 & 11.15 & 5.27 & 0.00 \\
\hline 126 & Slope larch pine with mixed undergrowth & 141.43 & 3.06 & 9.12 & 11.79 \\
\hline 127 & Slope with herbal dumetosous undergrowth & 513.18 & 12.78 & 3.01 & 0.10 \\
\hline
\end{tabular}




\begin{tabular}{|c|c|c|c|c|c|}
\hline 128 & $\begin{array}{l}\text { Slope herbal with undergrowth of Daurian } \\
\text { rhododendron, steppizated }\end{array}$ & 489.33 & 7.30 & 3.30 & 2.69 \\
\hline & \multicolumn{5}{|c|}{ XX Piedmont subtaiga pine } \\
\hline 132 & $\begin{array}{l}\text { Flat with undergrowth of Dahurian } \\
\text { rhododendron }\end{array}$ & 252.21 & 25.28 & 0.00 & 0.00 \\
\hline 134 & $\begin{array}{l}\text { Piedmont plains, dumetosous -herbal, } \\
\text { steppizated }\end{array}$ & 498.62 & $\begin{array}{r}13.4 \\
3\end{array}$ & 7.65 & 6.41 \\
\hline \multirow[t]{2}{*}{138} & Valley steppizated meadows & 125.22 & 16.31 & 13.57 & 4.46 \\
\hline & \multicolumn{5}{|c|}{ A-4 Mountain and plain Amur-Sakhalin } \\
\hline & \multicolumn{5}{|c|}{ XXIII Piedmont subtaiga birch of Dahurian type } \\
\hline \multirow[t]{4}{*}{148} & $\begin{array}{l}\text { Piedmont plains, herbal in combination with } \\
\text { meadow steppes and shrubs }\end{array}$ & 26.85 & 1.11 & 0.00 & 6.39 \\
\hline & Total taiga: & 4227.10 & & & \\
\hline & \multicolumn{5}{|c|}{ B CENTRAL ASIAN STEPPE GEOSYSTEMS } \\
\hline & \multicolumn{5}{|c|}{ B-1 Mountain Western Tans-Baikal of Dahuriantype } \\
\hline 197 & Gently slope low-bunchgrass gramineous fescue & 53.04 & 3.45 & 0.05 & 15.69 \\
\hline 198 & Rocky slope short-grass and artemisia lithophile & 46.56 & 72.02 & 0.00 & 0.00 \\
\hline 199 & $\begin{array}{l}\text { Slope mesophitic mixed herbs fescue- } \\
\text { feathergrass }\end{array}$ & 14.84 & 1.26 & 11.65 & 0.00 \\
\hline 200 & Slope salsoletum- gramineous & 85.83 & 18.85 & 34.32 & 0.00 \\
\hline 201 & Gently slope herb-fescue-tansy & 332.65 & 2.35 & 3.03 & 6.49 \\
\hline 202 & $\begin{array}{l}\text { Basins bottoms (piedmont) tallgrass feather- } \\
\text { wheat grass }\end{array}$ & 90.28 & 95.77 & 0.00 & 0.00 \\
\hline 203 & $\begin{array}{l}\text { Piedmont (plains and the bottoms of } \\
\text { depressions) salsoletum- gramineous }\end{array}$ & 136.06 & 15.33 & 0.00 & 5.18 \\
\hline 204 & Terraces and trails, low bunchgrass lithophile & 225.06 & 6.48 & 13.61 & 4.97 \\
\hline 205 & $\begin{array}{l}\text { Bottoms of the basins, kobrezia-fescue and low } \\
\text { grass steppe meadow permafrost }\end{array}$ & 21.21 & 1.47 & 13.57 & 0.00 \\
\hline \multirow[t]{2}{*}{206} & $\begin{array}{l}\text { Valley sedge-gramineous meadow-bog } \\
\text { solonetzic }\end{array}$ & 699.79 & 10.10 & 10.37 & 1.83 \\
\hline & \multicolumn{5}{|c|}{ B-2 High Plains and denudation outliers Onon-Argunsk cyrophile } \\
\hline 210 & High denudation surfaces, prairie herbal-tansy & 279.98 & 6.78 & 17.54 & 1.91 \\
\hline 211 & Gentle slope feathergrass-tansy transitive & 2.25 & 0.36 & 0.00 & 0.00 \\
\hline 212 & $\begin{array}{l}\text { Piedmont plains tansy, mixed grass and } \\
\text { agricultural lands their }\end{array}$ & 0.77 & 0.02 & 7.91 & 4.12 \\
\hline 213 & Flat interfluve mixed feathergrass & 299.64 & 12.15 & 18.23 & 0.03 \\
\hline 214 & $\begin{array}{l}\text { Gently slope salsoletum - feathergrass combined } \\
\text { with fescue steppes }\end{array}$ & 424.09 & 20.91 & 29.94 & 0.00 \\
\hline 215 & $\begin{array}{l}\text { Valley meadow, of willow-poplar type, } \\
\text { steppizated }\end{array}$ & 411.22 & 4.88 & 12.81 & 5.22 \\
\hline 216 & $\begin{array}{l}\text { Gentle slope (in depressions) cleistogenes- } \\
\text { aneurolepidium }\end{array}$ & 138.79 & 2.60 & 18.89 & 5.43 \\
\hline 217 & $\begin{array}{l}\text { Folds bottoms, low bunchgrass spotted in } \\
\text { combination with halophytic-meadow }\end{array}$ & 354.41 & 9.15 & 1.21 & 4.21 \\
\hline 218 & $\begin{array}{l}\text { Lowland meadow iris combined with } \\
\text { aneurolepidium-steppes and salt marshes }\end{array}$ & 319.84 & 16.18 & 1.60 & 7.52 \\
\hline 219 & Valley meadow-bog, sometimes saline & 133.71 & 4.56 & 3.57 & 9.87 \\
\hline
\end{tabular}




\begin{tabular}{|c|c|c|c|c|c|}
\hline & Total steppe: & 4075.43 & & & \\
\hline & Total & 8302.53 & & & \\
\hline
\end{tabular}

In general, the high heterogeneity of the environment defined the mosaic combination of different steppe areas whereas continental climate and basin type of the relief defined their penetration into the neighbouring mountain-taiga ecosystem. According to the areas ratios the share of steppe landscapes in the planned transport corridor is $49 \%$. During the intensive agricultural development (in 1970-1980-ies) about 40\% of Dauria steppe landscapes were plowed, the rest were more or less intensively used as grazing lands [65].

Among the main threats to the steppe areas in the present time can be identified: destruction of ecosystems and their components as a result of mining production, domestic and industrial pollution, numerous vast grassland fires, vegetation and soil degradation as a result of overgrazing, reduced resilience of ecosystems as a result of species and landscape diversity reduction. The region is characterized by a distinct climate cycles and alternating 15-years drought and flood periods [66]. In case of anthropogenic violations natural ecosystems recover at a slower pace and during aridity cycles degradation processes are amplified by natural tendency.

The construction of new facilities potentially carries the risk of barriers to the migration of ungulates and amplifies disturbance [21]. Among steppe geosystems the anticipated impact area is characterized by very rare for TBT slope stony low forb Artemisia lithophile (198), folds bottoms, low-bushgrass spotted in combination with halophytic-meadow (217) geosystems. If the latters are sufficiently represented in other areas of TBT, the extinction danger of the firsts is amplified by the fact that the impact zone comprises $72 \%$ of their total area in TBT. Piedmont tallgrass feather-agropyron landscape (202) are also endangered, 95.7\% Transbaikalian areas of which fall in the impact zone of the planned HSR.

Boreal landscapes are represented by the groups of Baikal Dzhugdzhur mountain taiga landscapes, which are differentiated by the environmental conditions for optimal, limited and reduced development subgroups, and South Siberian piedmont and mountain subtaiga landscapes. The most typical geosystems are slope larch, larchbirch and larch-pine forests with mixed undergrowth. In TBT there are very limited number of the analogues of Southern Siberia natural geosystems (dark coniferous and pine subtaiga geosystems) and representatives of the Amur-Sakhalin subtaiga area. The suppositional impact corridor will cover the territory of the valleys, alluvial cones, lower parts and foot of the slopes, so here we deal with a number of geosystems, stenotopic in TBT.

Slope larch pine grass-cowberry (81) landscapes are the rarest of TBT taiga geosystems. They cover only a very small proportion of the territory of TBT - less than $0.01 \%$, but $99 \%$ of which fall in the impact corridor of the planned HSR. Transbaikalian rare landscapes include Amur-Sakhalin landscapes formations. The impact zone includes an area of piedmont subtaiga birch landscapes of Dahurian type with meadow steppes and bushes (148), but the share of this area in the total area of the geosystem of this type in TBT is $1.1 \%$. And it is almost completely affected by human activities so far.

All completely or partially pine landscapes are of special natural and economic value $(125,126,127,128$, $134,138)$, but they are significantly violated by logging and fires [67-68]. All pine landscapes have limited distribution, in Transbaikalian landscape structure their share ranges from $0.16 \%$ to $1.55 \%$ [22]. The new project endangered plain and valley subtaiga pine landscapes with Dahurian rhododendron undergrowth (132) which represent pine forests, limitedly located on the sides of the rivers valleys confined to sandy soils. The planned transport corridor comprises about $25 \%$ of this landscape area in TBT. Currently, this landscape is already significantly violated along the railway line. According to estimates, from 60 to $80 \%$ of its area were subjected to cutting downs, fires or are allocated for building construction. For this reason its territory in the impact corridor cannot be included in NPAs of the region. It is necessary to find other areas that remained the most pristine.

Extensive annually recurring forest fires, illegal logging, destruction of natural complexes components as a result of mining production, which collectively lead to substantial reduction in the area of natural geosystem and landscapes fragmentation are among the main threats to taiga regions of TBT. Climate cyclicity also has an impact on the state of taiga geosystems: a significant increase in the number and area of fires in drought cycles is registered [19].

Increase of population growth and urbanization lead to increased burden on landscapes and their subsequent fractures. It is so-called deferred construction effect which must also be taken into account when predicting the load on the region ecosystems and planning environmental protection measures. In general natural complex loss risks decrease if a landscape is widespread and decrease much more significantly if it is included in the existing NPAs network. Thus, the landscapes numbered 47, 48, 73, 74, 76 and 79 can be referred to widespread ones. The landscapes numbered $58,88,92,200,214$, can be referred to landscapes adequately represented in the existing NPAs (Table 1). The most endangered are: 
- All the rare geosystems discussed above $(81,132,198,217,202)$;

- The landscapes which are not included in the currently existing NPAs network $(85,148,197,202,203$, 211);

- The landscapes the share of which in the region NPAs is less than $2 \%(71,217,218)$.

To reduce the risk of loss and mitigate the impact on natural ecosystems the compensatory measures are needed. They should be directed to the inclusion of these landscapes in the NPAs net.

The current network of specially protected natural territories of TBT includes 91 NPAs of different categories: 2 reserves, 3 national parks, 2 state nature reserves of federal status; 17 state nature reserves of regional status; 2 nature parks and 65 natural monuments. "The concept of development of the system of specially protected natural areas of regional status in Trans-Baikal Territory for the period till 2030" (Concept) adopted in March 2016 determines the main directions of NPAs system development and envisages the procedure for information update and supplement in order to improve and increase the efficiency of the region's NPA system. Currently the Concept envisages plans for NPAs net development in TBT. A part of the territories of high environmental value comprising vulnerable geosystems is included in projects for the creation of NPAs of regional status. However, a number of landscapes still need to be included in this program.

As for the risks and threats of the projected HSR impact on the existing NPAs system of the region, in accordance with the proposed track variant (Figures 2 and 4) it does not cross the boundaries of any nature protected area. However, in the vicinity of HSR there are several NPAs (Figure 4) the environment formation and, consequently, security function of which is under the threat. These are the State Nature Biosphere Reserve "Daursky" (northern cluster and "Adon-Chelon" area), the federal reserve "Dzeren Valley", the natural park "Ivano-Arahleyskiy" and 14 natural monuments.

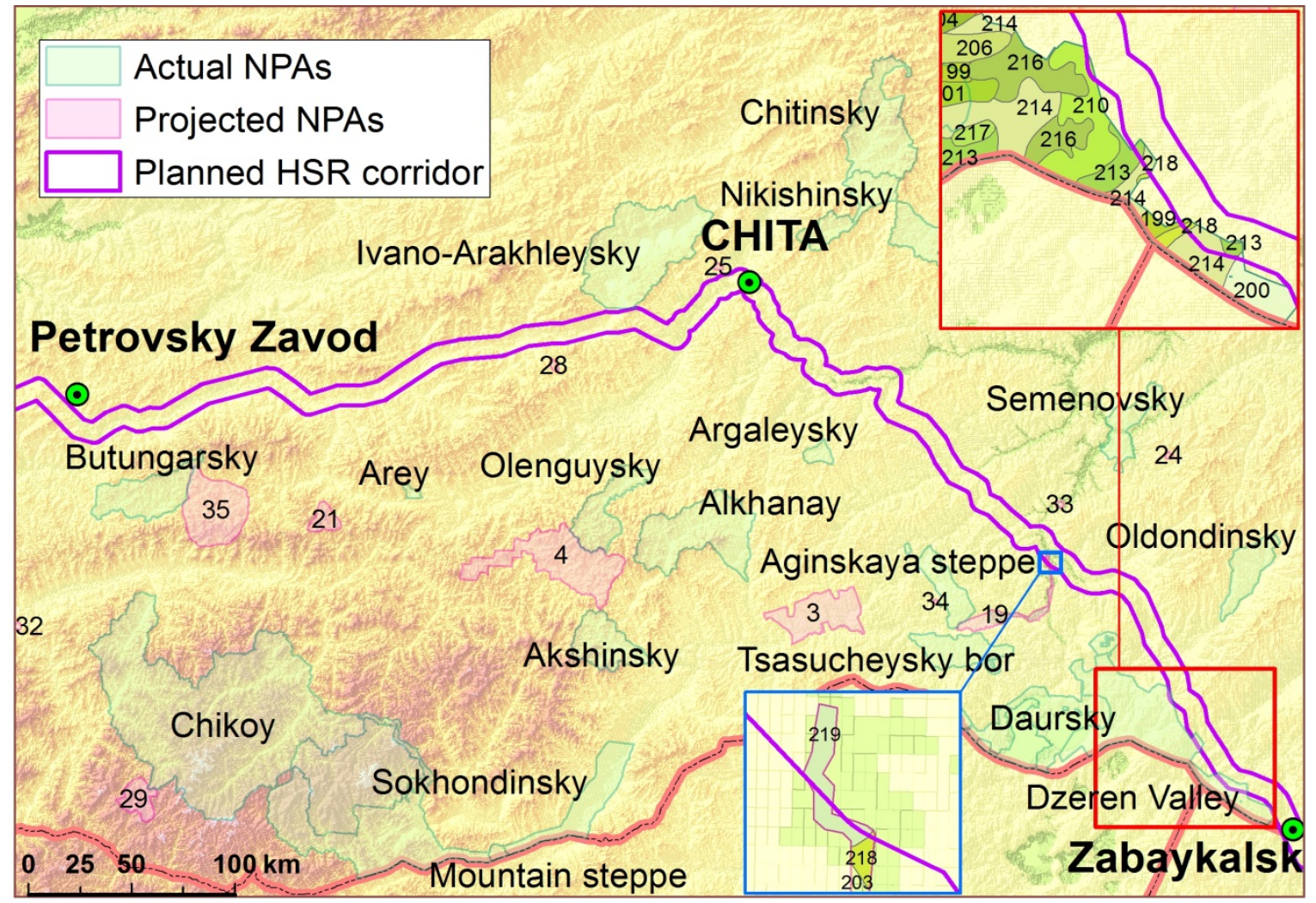

Figure 4: Natureprotected areas and HSR line.

The numbers on the map represent the following projected NPAs (according to the Concept):

3 - The state natural complex reserve "Duldurginsky";

4 - The state natural complex reserve "Dzhilinsky";

19 - The state natural complex reserve "Ichthyocenoses of Onon River";

21 - The state natural complex reserve "Khiloksky";

22 - The state natural complex reserve "Khiloksky steppe region";

25 - Geological natural monument "Red Hill";

28 - Botanical natural monument "Big Ulyotka Spruce Forest"; 


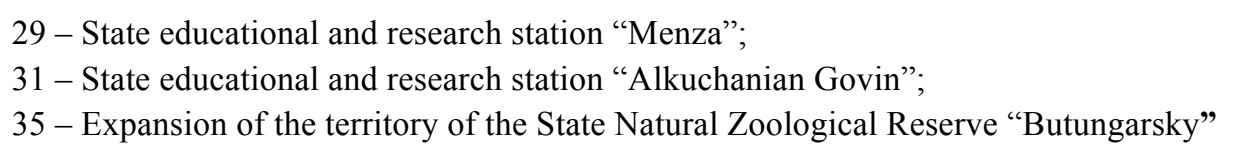

In accordance with the Conception of the development of the systems of NPAs of regional status in TBT for the period up to 2030 it is planned to create some more NPAs of regional status, which could potentially be impacted during the construction or operation of HSR along the lines of transport direction under study. These areas include natural complex reserve "Urulyunguysky" (creation in 2016-2018), complex reserve "Ichthyocenoses of Onon River" (creation in 2022-2024), complex reserve "Khiloksky" (creation in 20242026), complex reserve "Khiloksky steppe region" (creation in 2028-2029), state educational and research station "Alkuchanian Govin" (creation in 2017-2019), geological natural monument "Red Hill" (creation in 2019). HSR projected line doesn't cross the preliminary boundaries of these NPAs, but 10-km possible impact buffer zone crosses several NPAs: the extreme north-eastern section of the projected reserve "Ichthyocenoses of Onon River"; geological natural monument "Red Hill" (Chita) and botanic natural monument "Big Ulyotka Spruce Forest".

The 10-km buffer zone intersects following landscapes in the territory NPAs (Figure 4): slope mesophitic mixed herbs fescue-feathergrass (199), slope salsoletum-gramineous (200), high denudation surfaces, prairie herbal-tansy (210), flat interfluve mixed feathergrass (213), gently slope salsoletum-feathergrass combined with fescue steppes (214), folds bottoms, low bunchgrass spotted in combination with halophytic-meadow (217), lowland meadow iris combined with aneurolepidium-steppes and salt marshes (218), boreal landscape planed surfaces with mixed undergrowth, with a predominance of bushy birches (47), slope, with dumetosous undergrowth, with a predominance of Dahurian rhododendron (74). In this situation, there is no safety guarantee for geosystems with 217 and 218 numbers since the risk of their losses will increase further. So measures are needed to mitigate the impact. The greatest influence may be on the federal reserve "Dzeren Valley" since there will be more than $88 \mathrm{~km}^{2}$ of its area in the $10-\mathrm{km}$ buffer zone.

\section{Conclusions and recommendations}

The studies and spatial analysis results allow authors to draw the following conclusions.

Trans-Baikal part of this high-speed railway line route variant in the section Zabaykalsk station - Chita station - Petrovsky Zavod Station will pass though the territory occupied by the three types of geosystems: boreal (taiga), subboreal semihumid (forest-steppe) and semi-arid (steppe). HSR transport corridor won't cross the borders of NPAs, currently existing in TBT.

43 out of 122 natural complexes located in TBT are subject to this project negative impact risks. Rare landscapes (5 types) and landscapes that are not included in the existing network of NPAs (6 types) are at the greatest risk as well as those of geosystems, the total share of which in NPAs network is very small (less than 2\%) (3 types).

However, it should be noted that, from an environmental point of view at the moment, this route (along the existing parcel trunk-railway) is the best route,becauseit will pass through already disturbed areas. Moreover,the implementation of the recommendations below will contribute to achieving the maximum effectfor reducing the impact on the geosystems.

To reduce the risk of loss and mitigate the impact on natural ecosystems the following measures are recommended at the design stage:

- HSR line should be designed taking into account a territory landscape structure in order to possibly eliminate the risk of losing rare geosystems and minimize the possible impact on natural systems. Considering the high environmental value and vulnerability of separate landscapes, there should not be planned any major railway nodes and other infrastructure facilities. In these areas can be through railway lines only;

- landscapes, the risk of loss of which cannot be excluded should be included into the existing network of regional NPAs as compensation measures;

- 200-meter overpasses to reduce landscape fragmentation effect and preserve migration corridors for animals should be envisaged;

- the route should pass through the previously anthropogenically affected areas only;

- the territories of rare for TBT landscapes should be excluded from projection zone (area of intense HSR exposure) especially during the construction: slope stony short-grass artemisia lithophile (198), slope pine-larch cowberry forb (81) landscapes; 
- subtaiga pine geosystems with the undergrowth of Dahurian rhododendron (132), piedmont larch taiga meadow with gramineous cover (85), folds bottoms, low bunchgrass spotted in combination with halophytic-meadow (217), lowland meadow iris combined with aneurolepidium-steppes and salt marshes (218) in the areas, where they are preserved in the most pristine state should be included in the integrated of Transbaikalian NPAs development scheme.

The authors believe that taking into account of the natural and territorial characteristics of the Trans-Baikal Territory when designing transport infrastructure in its territory in the framework of China Silk Road Economic Belt initiative will not contradict the stated environmental objectives of the strategy - environmental safety. The implementation of the proposed measures to eliminate and reduce risks for natural complexes will contribute to the sustainable economic development of the region areas surrounding the transport corridor. And it will allow us to hope that the New Silk Road will be a way to "green" economy for the Trans-Baikal Territory [15].

Acknowledgments-The authors express their sincere gratitude to Professor Irina Glazyrina, Olga and Anastasia Kirilyuk for their attention to this work, provided materials, help and advice in the course of the article writing.

\section{References}

1. L.A. Bezrukov. Geogr. Nat. Resour. 3 (2014) 199-207.

2. M. Zhang.Value Eng. 11 (2010) 227-228.

3. B. Otgonsuren. ERINA Rep. 127 (2015) 3-6.

4. I.P. Glazyrina, S.M. Lavlinskii, I.S. Kalgina.Geogr. Nat. Resour. 4 (2014) 359-364.

5. L.A. Bezrukov. ECO. 7 (2016) 21-36.

6. S. Dong, Z. Li, Y. Li, G. Shi, H. Yu, J. Wang, J. Li, Q. Mao, Y. Huang. J. Resour. Ecol. 2 (2015) 65-72.

7. M. Zhang, Q. Wu, D. Wu, L. Zhao, X. Liu. J. Chem. Pharm. Res. 8 (2014) 243-254.

8. H. Kim, S. Sultana. J. Transp. Geogr. 45 (2015) 48-61.

9. S. Masson, R. Petiot. Technovation. 29 (2009) 611-617.

10. Sh. Zhong, Y. Guo. Areal Res. Dev. 02 (2013) 46-51.

11. I.P. Glazyrina, A.A. Faleichik, L.M. Faleichik. Probl. Econ. Transit. 6 (2012) 43-62.

12. E. Vodichev, I. Glazyrina, B. Krasnoyarova. J. Geogr. Politics Soc. 2 (2016) 13-20.

13. I.A. Zabelina, E.A. Klevakina. Probl. Econ. Transit. 7(2012) 39-48.

14. I.P. Glazyrina, L.M. Faleychik, K.A. Yakovleva. Geogr. Nat. Resour. 4 (2015) 327-334.

15. I.P. Glazyrina, I.A. Zabelina. J. Resour. Ecol. 5 (2016) 342-351.

16. A. Seiler, J.-O. Helldin. Nat. Conserv. 11 (2015) 5-12.

17. G.S. Samoilova, I.A. Avessalomova. Geogr Quest. 137 (2014) 39-62.

18. Transbaikalia Atlas (Buryat ASSR and Chita Region). Moscow-Irkutsk: SDGS (1967)

19. V.A. Obyazov. Dokl Earth Sci. 2 (2015) 375-378.

20. O.K. Kirilyuk. Probl. Contemp. Sci. Pract. Vernadsky Univ. 8 (2009) 144-151.

21. O. Kirilyuk, V. Kirilyuk, N. Maksakovsky, S. Kobyakova, O. Goroshko, T. Tkachuk, A. Butorin, A. Namkhai, N. Urtnasan, N. Tseveenmyadag, et al. Landscapes of Dauria. potential serial transnational world heritage propertyMoscow, ANNIE,(2013).

22. N.V. Pomazkova, L.M. Faleychik. Transbaikal State Univ. J. 9 (2013) 23-36.

23. M.A. Udvardy. IUCN Occasional Pap. 18 (1975) 5-47.

24 S.P. Brady, J.L. Richardson. Front Ecol Environ. 15 (2017) 91-98.

25. R.T.T. Forman, L.E. Alexander. Annu. Rev. Ecol. Syst. 29 (1998) 207-232.

26. K.H. Riitters, J.D. Wickham. Front. Ecol. Environ. 3 (2003) 125-129

27. W.R. Black. In: G.L. Gaile, C.J. Wilmott (Eds). Geography in America. Columbus, Merrill (1989) 316-332.

28. D. Gordon. Steering a new course: transportation, energy, and the environment. Washington (DC), Island Press, (1991)

29. C. Hunter, J. Farrington, W. Walton. Transport and the environment. In: B. Hoyle, R. Knowles (Eds). Modern Transport (1998)

30. R.T.T. Forman, D. Sperling, J.A. Bissonette, A.P. Clevenger, C.D. Cutshall, V.H. Dale, L. Fahrig, R. France, C.R. Goldman, K. Heanue, et al. Road ecology: science and solutions. Washington (DC), Island Press, (2003)

31. M. Janic. J. Mod. Transp. 1 (2016) 1-21

32. EPA, Indicators of the Environmental Impacts of Transportation: Highway, Rail, Aviation, and Maritime Transport, EPA 230-R-96-009 (1996). 
33. D.J. Oxley, M.B. Fenton, G.R. Carmody. J. Appl. Ecol. 11 (1974) 51-59.

34. C. Nellemann, I. Vistnes, P. Jordhoy, O. Strand. Biol. Conserv. 3(2001) 351-360.

35. P.F. Develey, P.C. Stouffer. Conserv. Biol. 15 (2001) 1416-1422.

36. M. Bhattacharya, R.B. Primack, J. Gerwein. Biol. Conserv. 109 (2003) 37-45.

37. A. Andrews. Aust Zool. 23 (1990) 130-141.

38. Forman, R.T.T.; Friedman, D.S.; Fitzhenry, D.; [and others]. Ecological effects of roads: Toward summary indices and an overview of North America. Canters, K.; Piepers, A.; Hendriks-Heersma, D. (eds). Proceeding of the international conference "Habitat fragmentation, infrastructure, and the role of ecological engineering," 17-21 September 1995, Maastricht-The Hague.Delft: The Netherlands: Ministry of Transport, Public Works, and Water (1997) 40-54

39. T.J. Hawbaker, V.C. Radeloff. Conserv. Biol. 5 (2004) 1233-1244.

40. G.E. Jr. Heilman, J.R. Strittholt, N.C. Slosser, D.A. DellaSala. Biosci. 55 (2002) 411-422.

41. R.A. Reed, B.J. Johnson, W.L. Baker. Conserv. Biol. 4 (1996) 1098-1106.

42. S.C. Saunders, M.R. Mislivets, J. Chen, D.T. Clelan. Effects of roads on landscape structure within nested ecological units of the Northern Great Lakes Region, USA. Biol. Conserv. 2 (2002) 209-225.

43. J.R. Strittholt, D.A. DellaSala. Conserv. Biol. 6 (2001) 1742-1754.

44. Y.H. Chen, Z. Zhu. J. Tongji.Univ. 6 (1997) 640-644.

45. M. Li, H.Q. Zhu, Y.L. Cai. Territ. Nat. Resour. Stud. (2) (2002) 42-44.

46. Y. Qian, H. Zhou, Z. Wu. J. Arid. Land. 1 (2010) 20-25.

47. L. Ries, R.J. Fletcher, J. Battin, T.D. Sisk. Annu.Rev. Ecol. Evolution Syst. 35 (2004) 491-522.

48. C. Hoban, K. Tsunokawa(Eds) Roads and the environment: a handbook World Bank technical paper, no. WTP 376. Washington (DC), The World Bank ISSN: 0253-7494 (1997)

49. M. Gontier. Integrating Landscape Ecology in Environmental Impact Assessment using GIS and Ecological Modelling. In: B. Trees, G. Trees, G. Fry, P. Opdam (Eds). From landscape research to landscape planning: aspects of integration, education and application. The Netherlands, Springer, (2006)

50. P. Banerjee, M.K. Ghose. Impact Assess. and Proj. Apprais. 4 (2016) 279-293.

51. L.M. Faleychik, E.A. Pyanova. Transbaikal State Univ. J. 50 (2008) 117-127.

52. L.M. Faleychik. Vestn. Novosib. Gos. Univ., Ser.: Inf. Technol. 2 (2012) 14-24.

53. L.M. Faleychik. Transbaikal State Univ. J. 8 (2014) 38-51.

54. V.I. Gilfanova, L.M. Faleychik.Izv. Ross. Akad. Nauk. Ser. Geog. 5 (2014) 116-124.

55. E.A. Pyanova, L.M. Faleychik.Comput. Technol.1 (2012) 109-119.

56. E.A. Pyanova, V.V. Penenko, L.M. Faleychik. Proc. SPIE 9292, 20th International Symposium on Atmospheric and Ocean Optics: Atmospheric Physics, 929247 (25 November 2014).

57. E.A. Pyanova, V.V. Penenko, L.M. Faleychik.Proc. SPIE 10035, 22nd International Symposium on Atmospheric and Ocean Optics: Atmospheric Physics, 100356D (29 November 2016).

58. E.A. Pyanova, V.V. Penenko, L.M. Faleychik. Proc. SPIE 10466, 23nd International Symposium on Atmospheric and Ocean Optics: Atmospheric Physics, 104666J (30 November 2017)

59. E.A. Pyanova, V.V. Penenko, L.M. Faleychik. Interexpo Geo-Sib. 1 (2017) 82-87.

60. N.V. Pomazkova, L.M. Faleichik, O.K. Kirilyuk. Sustain. Dev. Mt. Territ. 3 (2012) 183-189.

61. N.V. Pomazkova, O.K. Kirilyuk, L.M. Faleychik.Vestn. Sib. State Univ. Geosystems. Technol. (SSUGT). 4 (2016) 208-222.

62. A. Jarvis, H.I. Reuter, A. Nelson, E. Guevara. Hole-filled SRTM for the globe Version 4, available from the CGIAR-CSI SRTM 90 m Database) (2008).

63. V.S. Mikheev, V.A. Ryashin. V.B. Sochava (Ed.). Landscapes of the south of the Eastern Siberia. Map of $1: 1500000$ scale. Moscow, SDGS,(1977).

64. A.V. Galanin, A.V. Belkovich. Rhythms and catastrophes in vegetation cover: desertification of Dahuria. Vladivostok: Botanical Garden-Institute FEB RAS, (2009) 17-36.

65. V.E. Kirilyuk, V.A. Obyazov, T.E. Tkachuk, O.K. Kirilyuk. M.J.A. Werger, M.A. van Staalduinen (Eds.). Eurasian Steppes. Ecological problems and livelihoods in a changing world. Dordrecht Heidelberg New York London, Springer (2012) 397-424.

66. V.E. Kirilyuk. Steppe Bull. 28 (2010) 29-33.

67. V.Z. Bagova, L.M. Faleychik. Geogr. Nat. Resour. 1 (2006) 54-59.

68. V.P. Makarov, O.F. Malykh, I.V. Gorbunov, L.N. Pak, T.V. Zhelibo, E.A. Banschikova. Adv. Curr. Nat. Sci.10 (2016) 79-83. 
(2018) ; http://www.jmaterenvironsci.com 